\title{
Suicidal deaths in females of central India, Indore region
}

\author{
Pankaj Verma $^{1^{*}}$, Pooja Misar ${ }^{2}$ \\ ${ }^{\mathbf{1}}$ Assistant Professor, ${ }^{\mathbf{2}}$ Senior Lecturer, ${ }^{\mathbf{1}}$ Dept. of Forensic Medicine and Toxicology, ${ }^{\mathbf{2}}$ Dept. of Conservative Dentistry and Endodontics, \\ ${ }^{1}$ SMBT IMSRC, Nashik, Maharashtra, ${ }^{2}$ SMBT Institute of Dental Sciences, Nashik, Maharashtra, India
}

"Corresponding Author: Pankaj Verma

Email: dr.pankajfmt@gmail.com

\begin{abstract}
Introduction: Pattern of suicidal deaths reflects social as well as the mental status of a country. As per the present study, the maximum number of cases belonged to 25 to 28 years age group. Maximum numbers of cases belonged to the joint family and lower middle class. $45 \%$ of females died within 1 year of their marriage, with $38 \%$ deaths between 6 months to 1 year of marriage. The most common cause of death was burning i.e. $76 \%$. Ill-treatment by the husband or his relatives for dowry was the most common reason for motivating females to commit suicide.

Objective: The aim of the current study was to find out the various causes of suicidal deaths in females married within 7 years of their marriage.

Materials and Methods: The present study was conducted in the Emergency Department and The Department of Forensic Medicine and Toxicology in which 114 autopsy cases with the history of suicide or attempted suicide in married females within seven years of their marriage were taken. The autopsy was conducted in Mortuary of Sri Aurobindo Medical College, Indore (MP) from June 2013 to February 2018.

Results: The most common cause of death was burn (76\%) followed by hanging $(13.15 \%)$ and poisoning $(8 \%)$.

Conclusion: On one side women are respected as Goddess in our culture, but on the other side they are ill-treated. Creating problems for women for dowry and suffocating their lives is one of the most heinous crimes. Its elimination can be done only by educating and empowering woman and to make strict laws against such crimes.
\end{abstract}

Keywords: Burn, Hanging, Married females, Mortuary, Poisoning, Suicidal deaths.

\section{Introduction}

Suicide

Suicide is the act of taking one's own life voluntarily.,

\section{Dowry}

The, ornaments, money, property or any other form of wealth which a bridegroom or his family receives from his bride or her family at the time of marriage. ${ }^{3}$

In current as well as the past scenario of India, women are adored as "Goddess", but on another side, they are subjected to cruelty which suffocates their lives and forces them to end up their lives by committing suicide. It is one of the most heinous crimes of mankind and it definitely reflects the social health of any community.

It is quite common to see in the news that a young woman has been burnt by their in-laws for not fulfilling the never-ending demands of dowry. Cruelty increases up to such a level that suicide remains the only way to get rid of such pain.

Hunger of dowry which never ends and due to that the brides are tortured mentally as well as physically. Such situations abet them to commit suicide by burning, hanging and poisoning, etc. Quarrels in the family which occurs mostly in joint families, infertility, and mal-adjustment are also some frequent reasons for such deaths. A large number of females are burnt alive by their husbands or in-laws or sometimes they are first killed and then burnt to hide the crime.

Suicidal death is a very big challenge to our society, police, and forensic experts as well as to the courts. The rate of unnatural deaths in newly married females has increased in the last few decades. ${ }^{4}$

\section{Legal Aspects}

IPC S. 304-B (Dowry Death) ${ }^{1,5}$

1. Death of a woman is caused by any burn or bodily injury under normal circumstances.

2. The death occurred within seven years of her marriage.

3. She was subjected to harassment or cruelty by her husband or his relative before her death.

4. Such harassment or cruelty should be in demand for dowry.

5. Shall be punished with imprisonment of not less than ten years, but which may extend to life imprisonment.

IPC S. 498-A ${ }^{6}$

1. Whoever, husband or relative of husband of a woman subjects her to cruelty (mental or physical)

2. Harassment to meet any unlawful demand for any property or valuable security.

3. Shall be punished with imprisonment up to three years and shall be liable to fine.

Cr PC S. $176(3)^{7}$ - Magistrate inquest in the death of a woman within seven years of her marriage if:

1. Suicide by a woman

2. In suspicious circumstances

3. Any relative made a request for foul play.

Various other laws in relation to this are IEA S. 113 (A) and $113(\mathrm{~B}){ }^{8}$

\section{Materials and Methods}

This was a retrospective study conducted in the Emergency Department and the Department of Forensic Medicine and Toxicology, at Sri Aurobindo Medical College, Indore 
Table 1: Demographics.

\begin{tabular}{|c|c|c|c|}
\hline Number of Females & $\begin{array}{c}<20 \text { Years- } 11.40 \% \\
21-24 \text { Years- } 43.85 \% \\
25-28 \text { Years- } 35.08 \% \\
>29 \text { Years- } 9.64 \%\end{array}$ & Method of Suicide & $\begin{array}{c}\text { Burn- } 76.31 \% \\
\text { Hanging- } 13.15 \% \\
\text { Poison- } 7.02 \% \\
\text { Unknown- } 2.63 \%\end{array}$ \\
\hline Time Since Marriage & $\begin{array}{c}<6 \text { Months- } 7.02 \% \\
6 \text { Months- } 1 \text { Year- } 37.72 \% \\
1-2 \text { Years- } 16.67 \% \\
2-3 \text { Years- } 16.67 \% \\
\text { 3- } 4 \text { Years- } 10.53 \% \\
\text { 4- } 5 \text { Years- } 6.14 \% \\
>5 \text { Years- } 5.30 \%\end{array}$ & Literacy & $\begin{array}{c}\text { Illiterate- } 19.30 \% \\
\text { Primary- } 28.10 \% \\
\text { High Secondary- } 31 \% \\
\text { Graduate- } 20.20 \% \\
\text { Post Graduate- } 2 \%\end{array}$ \\
\hline Type of Family & $\begin{array}{c}\text { Joint- } 72 \% \\
\text { Nuclear- } 28 \% \\
\end{array}$ & Residence & $\begin{array}{c}\text { Rural- } 53.51 \% \\
\text { Urban- } 46.50 \% \\
\end{array}$ \\
\hline Religion & $\begin{array}{l}\text { Hindu- } 99.12 \% \\
\text { Muslim- } 0.08 \%\end{array}$ & $\begin{array}{l}\text { Socio Economic } \\
\text { Class }\end{array}$ & $\begin{array}{c}\text { Lower Class- } 10.53 \% \\
\text { Upper Lower- } 29 \% \\
\text { Lower Middle- } 41.23 \% \\
\text { Upper Middle- } 18.42 \% \\
\text { Upper Class- } 0.90 \%\end{array}$ \\
\hline $\begin{array}{l}\text { Duration between Death } \\
\text { and Incidence }\end{array}$ & $\begin{array}{c}<12 \text { Hours- } 6.14 \% \\
\text { 12- } 24 \text { Hours- } 15 \% \\
1-3 \text { days- } 18.42 \\
\text { 4-7 Days- } 27.20 \% \\
\text { 8- } 15 \text { Days- } 10.53 \% \\
>15 \text { Days- } 2.63 \% \\
\text { Brought Dead- } 20.20 \%\end{array}$ & & \\
\hline
\end{tabular}

(M.P) in which 114 autopsy cases with a history of suicide or attempted suicide in females married within seven years were taken. The autopsy was conducted in Mortuary of the same institution from June 2013 to February 2018 in the presence of female gynecologists. The information was collected from police, relatives, hospital records and friends. A special Proforma had been designed and all the data had been collected in a master chart in Excel worksheet and analyzed.

\section{Observation}

As per this present study, it was observed that the maximum number of cases belonged to 21-24 years age group i.e. $43.85 \%$, followed by age group $25-28$ years $(35.08 \%)$. This may be due to the reason that up to 24 years both the partners are not enough mature to handle the marital obligations. Rural cases $(53.51 \%)$ were more than that of the urban cases $(46.5 \%)$, and the reason behind this may be that dowry is still more rooted in rural areas and presence of joint family which creates more family issues. The maximum number of cases belonged to the Hindu community (99.12\%) and rest were from the Muslim community $(0.08 \%)$. Mostly incidence occurred between 6 months to 1 year of duration after marriage, may be because in first half year both the partners are trying to know each other but after that various martial issues as well as demands of dowry starts. Table 1 .

\section{Discussion}

Indore is the most populous and the largest city of Madhya Pradesh which is an educational hub, as it is the only city which is having Indian Institute of Management and Indian Institute of Technology. The maximum number of cases belonged to the third decade followed by the second decade. Similar results were observed in various other studies. ${ }^{9-11}$

The maximum number of deaths occurred within 1 year of their marriage i.e. $45 \%$. This high percentage of deaths within 1 year is mainly due to dowry, new problems in new relations and lack of maturity. The burn was the most common cause of death i.e. $76.31 \%$ which is similar to various other studies. ${ }^{10-15}$ Mostly females remain at home and there is easy availability of kerosene or other cooking materials leads to committing suicide by burns.

The lower middle class was most prone for suicidal deaths in newly married females as per this study and similar results were observed by various studies. ${ }^{16}$ This may be due to economic instability which causes more violence against women as well as greedy for money in the form of dowry.

To reduce such crimes against women of our society, there is need of strict laws in our legislature or amendment in Dowry Prohibition Act, 1961, avoidance of early marriages, changing attitude by a man towards women, counseling by various agencies of Government as well as Non-Government Organizations to family members. ${ }^{17-19}$ Deterrent theory of punishment must be applied to such offenders who commit such heinous crimes.

\section{Conclusion}

Proper education, awareness, empowering women, making women independent will be a key to succeed in this matter. Biggest contribution will be to change our mentality and 
leaving our rudimentary thoughts. We should start such education not only from the schools but also at home by giving respect to women around us. This may be a very small step, but it will definitely affect the mentality of people and in a good way.

\section{Conflict of Interest: None.}

\section{References}

1. Reddy KSN. The Essentials of Forensic Medicine and Toxicology. $34^{\text {th }}$ edition. Jaypee Brothers Medical Publishers (O) Ltd 2017: 272-6.

2. Pillay VV. Textbook of Forensic Medicine and Toxicology. $15^{\text {th }}$ edition. Paras Med Publishers 2010:263-4.

3. Salim S. Dowry, Its Causes and Consequences: A Sociological Study of Dowry Harassment and Death Cases in Aligarh District of UP. Int J Sci Res Manag 2017; 5(10):7251-63.

4. Guntheti BK, Singh UP. A study of Unnatural Female Deaths reported to a tertiary care hospital in Khammam, Telangana. $J$ Indian Acad Forensic Med 2016; 38 (4):460-4.

5. Parmar P. Dowry Death and Law- Indian Scenario. Int Arch Integr Med 2014;1(2):44-9.

6. Bardale R. Principles of Forensic Medicine and Toxicology. $1^{\text {st }}$ edition. Jaypee Brothers Medical Publishers 2011:272-3.

7. Mathiharan K, Patnaik AK. Modi's Medical Jurisprudence and Toxicology. $23^{\text {rd }}$ edition. LexisNexis, Butterworths 2006:21-2.

8. Parikh CK. Parikh's Textbook of Medical Jurisprudence and Toxicology, $5^{\text {th }}$ edition. CBS Publishers and Distributers Pvt. Ltd.1996:385-6.

9. Sane MR. Unnatural Deaths of Adult Females in South Bangalore- An Autopsy Study. J Indian Acad Forensic Med 2014; 36(2):130-2.

10. Pathak A, Sharma S. The Study of Un-Natural Female Deaths in Vadodara City. J Indian Acad Forensic Med 2010; 32(3): 220- 3 .
11. Kulshrestha P, Sharma RK, Dogra TD. The study of sociological and epidemiological variables of unnatural deaths among young women in south Delhi within seven years of marriage. J Punjab Acad Forensic Med Toxicol 2002; 2: 7-17.

12. Zine KU, Mugadlimath A, Gadge SJ, Kalokhe VS, Bhusale RG. Study of some socio-etiological aspects of unnatural female deaths at Government Medical College, Aurangabad. $J$ Indian Acad Forensic Med 2009;31(3):210-7.

13. Dere RC, Rajoo KM. Study of Unnatural Deaths in Females, A Medico-legal Study at Rural Medical College, Loni. J Indian Acad Forensic Med 2011; 33(3): 211-3.

14. Srivastava AK, Arora P. Suspicious deaths in newly married females- a medico legal analysis. J Indian Acad Forensic Med 2007; 29(4):63-7.

15. Sharma BR, Singh VP, Sharma RS. Unnatural Deaths in Northern India- A Profile. J Indian Acad Forensic Med 2004;26(4):140-6.

16. Kulshrestha P, Sharma RK, Dogra TD. The Study of Sociological and Demographical Variables of Unnatural Deaths among Young Women in South Delhi within Seven Years of Marriage. Medico- Legal Update 2004; 4(1):5- 14.

17. Satpathy DK. Burning Brides- A medico-legal study. Med Law 1995;14: 547-52.

18. Bhullar DS et al. Profile of unnatural female deaths (between 18 of age) in Govt. Medical College/ Rajindra Hospital, Patiala (India). J Forensic Med Toxicology 1996;13(3, 4): 5.

19. Rao NKG. Study of fatal female burns in Manipur. J Forensic Med Toxicology 1997;14(2):57-9.

How to cite this article: Verma P, Misar P. Suicidal Deaths in Females of Central India, Indore Region. Indian J Forensic Community Med 2019;6(2):93-5. 